\title{
Kompetensi Pedagogik : Sebuah Tinjauan tentang Internalisasi Nilai-Nilai Karakter pada Pembelajaran Matematika SD
}

\author{
Sabaruddin ${ }^{1}$, Rita Sari $^{2}$, Rosnidar Mansor ${ }^{3}$ \\ ${ }^{1,2}$ Fakultas Tarbiyah dan Imu Keguruan, IAIN Langsa \\ ${ }^{3}$ Fakulti Pembangunan Manusia, University Pendidikan Sultan Idris (UPSI), Perak, Malaysia \\ e-mail: sabaruddin@iainlangsa.ac.id
}

\begin{abstract}
ABSTRAK. Pendidikan karakter merupakan aspek penting dari implementasi kurikulum 2013 (K13) yang menghendaki guru untuk menginternalisasikan nilai-nilai karakter pada semua materi ajarnya. Demikian pula dengan pelajaran matematika pada jenjang sekolah dasar (SD), guru dituntut memiliki kemampuan untuk memberikan pengalaman belajar yang bermakna dengan melibatkan penanaman nilai-nilai karakter pada materi ajarnya. Namun pada kenyataannya proses ini bukanlah sesuatu yang mudah karena guru harus memiliki sejumlah kompetensi yang mumpuni dalam mengajar, terutama kompetensi pedagogik. Jenis penelitian ini adalah penelitian deskriptif yang dilaksanakan mulai bulan April-Oktober 2018 yang melibatkan 43 orang guru SD di Kota Langsa. Adapun hasil penelitian menunjukkan bahwa (1) pemilihan model, metode, dan media pembelajaran serta sumber belajar matematika oleh guru kelas sudah sesuai dengan pertimbangan terhadap karakteristik siswa dan mata pelajaran; (2) namun ditemukan juga kendala pada implementasi nilai-nilai karakter yang tampak pada rencana kerja harian, hal ini disebabkan sebagian guru tidak paham terhadap perangkat ajar K-13 dan bahkan rencana kerja harian diambil secara langsung dari internet. Sehingga diharapkan kepada Dinas Pendidikan terkait untuk terus meningkatkan pelatihan bagi guru kelas terutama yang berkaitan dengan penyusunan rencana kerja harian sesuai dengan $\mathrm{K}-13$
\end{abstract}

Keywords : kompetensi pedagogik, nilai-nilai karakter, dan pembelajaran matematika

\begin{abstract}
Character education is an important aspect of the implementation of the 2013 curriculum (K-13) which requires the teacher to internalize the character values of all the teaching material. Likewise with mathematics in elementary school (SD), teachers are required to have the ability to provide meaningful learning experiences by involving the planting of character values in the teaching material. But in reality this process is not something easy because the teacher must have a number of competencies that are qualified in teaching, especially pedagogical competencies. This type of research is a descriptive study conducted from April to October 2018 involving 43 elementary school teachers in Langsa City. The results of the study show that (1) the selection of learning models, methods, and media as well as mathematics learning resources by classroom teachers is in accordance with the consideration of student characteristics and subjects; (2) but also found obstacles to the implementation of character values that appear in the daily work plan, this is because some teachers do not understand the K-13 teaching tools and even daily work plans are taken directly from the internet. So it is expected that the relevant Education Office will continue to improve training for classroom teachers, especially those related to the preparation of daily work plans in accordance with $\mathrm{K}-13$
\end{abstract}

Keywords : pedagogic competence, character values, and mathematics learning

\section{PENDAHULUAN}

Permasalahan degradasi moral karakter sangat dirasakan dewasa ini (Yuyus Kardiman, 2013; Kristanto, 2011 dan Howard et. al, 2004). Bangsa Indonesia seyogyanya bangsa yang berkarakter dan beradap sesuai dengan budaya bangsa timur cinta dengan kedamaian, patriot dan agamais kini menjadi kenangan belaka. Banyak kasus-kasus yang yang terjadi dalam kehidupan 
sehari tidak menunjukkan sikap sebagaimana yang diharapkan seperti korupsi dikalangan penegak hukum dan pejabat pemerintahan, penyalahgunaan narkoba diberbagai kalangan masyarakat, melanggar aturan lalu lintas, membuang sampah sembarangan, kekerasan fisik di tempat umum, pelecehan seksual terjadi dimana-mana (Sumantri, 2010; Kristanto, 2011).

Tentunya masalah ini akan menjadi contoh buruk terhadap dunia pendidikan kita saat ini, anak-anak usia sekolah akan meniru apa yang terjadi di lingkungan mereka sehingga akan memicu sikap yang tidak bermoral pula. Bahkan lebih buruk lagi, apabila hal buruk terus ditontonkan maka akan tercipta generasi yang hedonisme, individualis, tidak bermoral, apatriotisme dan lebih parah akan muncul generasi-generasi yang radikalisme (Millati, 2016).

Saat ini implementasi kurikulum 2013 masuk tahun ke 4, dijenjang Sekolah Dasar (SD), pada tahun 2016, K-13 telah dilaksanakan di 37.034 sekolah. Sedangkan pada Tahun 2017/2018, Kemendikbud menargetkan sekolah yang akan menerapkan K-13 sebanyak 35\% sekolah sasaran baru atau sebanyak 52.572 sekolah, sehingga diharapkan sebanyak $60 \%$ dari seluruh SD telah menerapkan K-13 (Kemdikbud, 2017).

Berdasarkan penelitian yang telah peneliti kaji sebelumnya di Kota Langsa belum menerapkan kurikulum 2013 secara menyeluruh di tingkat Sekolah Dasar terutama dalam prosses pembelajaran di kelas. Masalah yang didapat di sekolah adalah belum adanya buku tematik pegangan guru dan murid, guru belum semuanya mendapatkan pelatihan kurikulum k-13, sarana pendukung tidak memenuhi standar k-13, orang tua murid kebanyakan belum paham bagaimana kurikulum yang sedang diterapkan disekolah dan pembelajaran terlihat masih sama dengan pola dalam kurikulum sebelumnya. Sehingga tiga hal penting yang menjadi agenda atau fokus utama yaitu (1) penguatan pendidikan karakter, (2) penguatan literasi, dan (3) pembelajaran abad 21 tidak mungkin tercapai dengan mudah.

Penerapan nilai-nilai karakter dalam pembelajaran menjadi amanat penting dalam kurikulum 2013, dimana pendidikan karakter tidak diajarkan melalui pembelajaran tertentu melainkan terintegrasi melalui semua pembelajaran termasuk pelajaran/topik matematika dalam tema-tema di Sekolah Dasar (Rahmi, 2013; Mulyasa, 2011; Howard et al., 2004). Pelaksanaan pembelajaran matematika yang terintegrasi dengan nilai-nilai karakter tidaklah mudah, guru perlu kemahiran pedagogik yang handal. Saat ini pembelajaran yang berlangsung belum terintegrasi dengan nilai karakter, pembelajaran terjadi satu arah yang berpusat kepada guru, yang seharusnya pembelajaran berpusat kepada siswa, guru lebih mementingkan penguasaan materi ajar dan menghabiskan bahan ajar semata. Pendekatan guru dengan murid terlihat tidak harmonis, guru lebih suka membuat murid susah dan terbeban secara fisik dan psikis (Sabaruddin, 2016). Guru juga kurang berkoordinasi dengan orang tua tentang perilaku anak-anak, orang tua juga kurang kepedulian terhadap karakter anak-anak baik disekolah maupun di rumah (Sabarudin, 2017). Hal ini yang menyebabkan tidak pendidikan karakter belum terealisasi dengan baik.

\section{Kompetensi Pedagogik Guru}

Menurut Standar Nasional Pendidikan, Kompetensi pedagogik adalah kemampuan seorang pendidik dalam mengelola pembelajaran peserta didik yang meliputi; pemahaman terhadap karakteristik peserta didik, merencanakan pembelajaran, melaksanakan pembelajaran, menyelenggarakan penilaian dan evaluasi proses dan hasil belajar, menfasilitasi pengembangan potensi peserta didik untuk mengaktualisasikan berbagai potensi yang dimiliki. Khususnya kemahiran guru dalam internalisasi nilai-nilai pendidikan karakter dalam semua pelajaran, guna menciptakan generasi cerdas dari segi intelektual, moral, sosial, wawasan kebangsaan dan terutama bertaqwa kepada Allah SWT.

Penelitian mengenai cara guru belajar untuk mengajar, Shulman (1987) telah menggunakan Model of Pedagogical Reasoning and Action. Terdapat enam komponen dalam model ini, iaitu 
kemampuan, transformasi, pengajaran, penilaian, refleksi dan pemahaman. Pemahaman ditujukan kepada guru dalam memahami konteks pembelajaran dan karakteristik murid. Memahami konten dan juga keadaan murid sangat penting untuk guru agar dapat menyesuaikan materi ajar dengan kemampuan dan kesesuaian dengan keadaan murid (Khofiatun, Sa'dun Akbar \& M. Ramli, 2016).

Komponen pengajaran dalam model ini merupakan aspek pedagogi yang terpenting melibatkan organisasi dan manajemen kelas, penjelasan serta uraian materi yang jelas, memberi dan memeriksa tugas murid, berinteraksi dengan pelajar secara efektif dengan soal-soal, jawaban dan respon serta pujian dan kritikan.

Kemampuan guru menyampaikan pengetahuan kepada berbagai kemampuan pelajar memerlukan suatu transformasi pengetahuan yang dimiliki oleh guru ke dalam bentuk yang mudah difahami oleh pelajar. Kualitas guru membawa pengaruh yang besar kepada kualitas dalam bidang pendidikan di mana kemampuan guru dalam melaksanankan pengajaran dan pembelajaran yang menarik dan bersesuaian dengan keadaan pelajar menjadi penentu keberhasilan proses pengajaran dan pembelajaran (Azizi Yahaya, Rosnani Mohd Nor, Sharifuddin Ismail, dan Amir Hamzah Abdul, 2010).

Oleh karena itu, guru perlu keterampilan, kemampuan dan mempunyai kepakaran baik di dalam atau pun di luar kelas. Meskipun seseorang guru itu mempunyai pengetahuan yang tinggi mengenai bidang kekhususannya, tetapi tidak mempunyai keterampilan dalam penyampaian ilmu tersebut, maka pengajaran yang efektif tidak dapat dicapai (Magdeline, Nur Ehsan, dan Zamri Mahamod, 2012). Dengan demikian, segala sesuatu persiapan guru sebelum masuk kelas untuk mengajar seperti materi ajar, media dan alat peraga yang teraencana dalam RPP sangatlah penting. Guru perlu memastikan proses pembelajaran yang disampaikan dalam keadaan tersusun, menarik, disampaikan dengan baik dan penuh keyakinan diri dan juga dalam masa yang sama mendorong dan meningkatkan minat siswa terhadap apa yang dipelajari (Azizi Yahaya et. Al, 2010).

Slamet mengatakan kompetensi pedagogik terdiri dari sub kompetensi (1) pemahaman wawasan atau landasan kependidikan oleh guru, (2) pemahaman terhadap peserta didik oleh guru, (3) pengembangan kurikulum dan silabus oleh guru, (4) perancangan atau perencanaan pembelajaran oleh guru, (5) pelaksanaan pembelajaran yang mendidik dan dialogis, (6) evaluasi hasil belajar, (7) pemanfaatan teknologi pembelajaran, dan (8) pengembangan peserta didik oleh guru (Syaiful Sagala, 2011).

\section{Pembelajaran Matematika SD}

Matematika merupakan proses penyusunan pola berfikir, pola mengorganisasikan pembuktian logik, pengetahuan struktur yang terorganisasi memuat sifat-sifat, teori-teori, dibuat secara deduktif berdasarkan unsur yang tidak didefinisikan, aksioma, sifat atau teori yang telah dibuktikan kebenarannya dengan jelas, tepat dan teliti (Hamzah, 2007; Depdiknas, 2003; Hudojo, 2005).

Ciri utama matematika adalah penalaran deduktif yaitu kebenaran suatu konsep atau pernyataan yang diperoleh sebagai akibat logis dari kebenaran sebelumnya. Namun demikian, dalam pembelajaran pemahaman konsep sering diawali secara induktif melalui pengalaman peristiwa nyata. Proses induktif-deduktif dapat digunakan untuk mempelajari konsep matematika. Selama mempelajari matematika dikelas, aplikasi hasil rumus atau sifat yang diperoleh dari penalaran deduktif maupun induktif sering ditemukan meskipun tidak secara formal hal ini disebut dengan belajar bernalar (Depdiknas, 2003).

Matematika dipandang sebagai suatu obyek abstrak dan banyak yang menganggap juga identik dengan angka-angka, tentu saja sangat sulit dapat dicerna anak-anak Sekolah Dasar (SD) yang sedang berada pada tahap operasi konkret berdasarkan klasifikasi oleh Piaget. Siswa SD belum mampu untuk berpikir formal maka dalam pembelajaran matematika sangat diharapkan 
bagi para pendidik mengaitkan proses belajar mengajar di SD dengan keadaan alam sekitar dan benda konkret (Hudojo, 2005).

Pembelajaran adalah proses yang diselenggarakan oleh guru untuk membelajarkan siswa dalam belajar yaitu belajar bagaimana memperoleh dan memproses pengetahuan, keterampilan, dan sikap (Mujiono, 2002). Heruman (2008) menyatakan dalam pembelajaran matematika SD, diharapkan terjadi reinvention (penemuan kembali). Penemuan kembali adalah menemukan suatu cara penyelesaian secara informal dalam pembelajaran di kelas.

Selanjutnya Heruman (2008) menambahkan bahwa dalam pembelajaran matematika harus terdapat keterkaitan antara pengalaman belajar siswa sebelumnya dengan konsep yang akan diajarkan. Sehingga diharapkan pembelajaran yang terjadi merupakan pembelajaran menjadi lebih bermakna (meaningful), siswa tidak hanya belajar untuk mengetahui sesuatu (learning to know about), tetapi juga belajar melakukan (learning to do), belajar menjiwai (learning to be), dan belajar bagaimana seharusnya belajar (learning to learn), serta bagaimana bersosialisasi dengan sesama teman (learning to live together).

Siswa Sekolah Dasar (SD) berada pada umur antara usia 7 hingga 12 tahun, pada tahap ini siswa masih berpikir pada fase operasional konkret. Kemampuan yang tampak dalam fase ini adalah kemampuan dalam proses berpikir untuk mengoperasikan kaidah-kaidah logika, meskipun masih terikat dengan objek yang bersifat konkret (Heruman, 2008).

Siswa SD masih terikat dengan objek yang ditangkap dengan pancaindra, sehingga sangat diharapkan dalam pembelajaran matematika yang bersifat abstrak, peserta didik lebih banyak menggunakan media sebagai alat bantu, dan penggunaan alat peraga. Karena dengan penggunaan alat peraga dapat memperjelas apa yang disampaikan oleh guru, sehingga siswa lebih cepat memahaminya.

Pembelajaran matematika di SD tidak terlepas dari dua hal yaitu hakikat matematika itu sendiri dan hakikat dari anak didik di SD. Tentunya dalam mengajarkan matematika di Sekolah Dasar tidak semudah dengan apa yang kita bayangkan, selain siswa yang pola pikirnya masih pada fase operasional konkret, juga kemampuan siswa juga sangat beragam. Demikian pula dengan penerapan nilai karakter dalam pembelajaran matematika memerlukan penguasaan pedagogi yang baik dan dukungan sikap guru dan yang terkait dengan pendidikan.

Tujuan dasar pengajaran dan pembelajaran matematika di sekolah dasar adalah memberikan kemampuan yang cukup bagi siswa untuk menghadapi materi-materi matematika pada tingkat pendidikan lanjutan (Prihandoko, 2006). Depdiknas menguraikan bahwa tujuan pembelajaran matematika adalah melatih dan menumbuhkan cara berfikir sistematis, logis, kritis, kreatif, dan konsisten, serta mengembangkan sikap gigih dan percaya diri dalam menyelesaikan masalah.

Untuk mencapai tujuan pembelajaran dengan baik, guru mestilah mampu mengorganisir semua komponen sedemikian rupa sehingga antara komponen yang satu dengan lainnya dapat berinteraksi secara harmonis. Salah satu komponen dalam pembelajaran adalah pemanfaatan berbagai macam strategi dan metode pembelajaran secara dinamis dan fleksibel sesuai dengan materi, karakteristik siswa dan konteks pembelajaran. Sehingga dituntut kemahiran guru untuk dapat memilih model pembelajaran serta media yang cocok dengan materi atau bahan ajar yang mendukung internalisasi nilai karakter dalam pembelajaran matematika (Sabaruddin, 2017; Muksetyo Gatoto, dkk, 2007).

\section{Internalisasi Pendidikan Karakter Pada Pembelajaran Matematika}

Kurikulum KTSP dan KBK telah melakasnakan pendidikan akhlak dan budi pekerti (pendidikan karakter), terutama melalui dua mata pelajaran Pendidikan Agama dan Pendidikan Kewarganegaraan dipandang masih belum maksimal dan berhasil dalam masyarakat (Marzuki, 2012). Oleh karena itu, pemerintah telah mengupayakan inovasi pendidikan karakter. Bahkan 
pemerintah telah mengupayakan memaksimalkan penerapan pendidikan karakter melalui kurikulum 2013 yang memfokuskan pendidikan kepada penguatan karakter, penguatan literasi dan peningkatan keterampilan. Inovasi tersebut adalah sebagai berikut:

1. Pendidikan karakter dilakukan secara terintegrasi ke dalam semua mata pelajaran. Integrasi yang dimaksud meliputi pemuatan nilai-nilai ke dalam substansi pada semua mata pelajaran dan pelaksanaan kegiatan pembelajaran yang memfasilitasi dipraktikkannya nilai-nilai dalam setiap aktivitas di dalam dan di luar kelas untuk semua mata pelajaran.

2. Pendidikan karakter juga diintegrasikan ke dalam pelaksanaan kegiatan pembinaan peserta didik.

3. Selain itu, pendidikan karakter dilaksanakan melalui kegiatan pengelolaan semua urusan di sekolah yang melibatkan semua warga sekolah (Dit. PSMP Kemdiknas, 2010).

Sumarmo (2011) mengungkapkan bahwa kekompleksan dalam pembelajaran matematika perlu dilihat dalam dua sudut pandang. Pertama, kemampuan pedagogi guru ditinjau dari topik yang diajarkan, karakteristik peserta didik, lingkungan belajar, serta karakteristik topik yang diajarkan. Kedua, perencanaan pembelajaran yang melibatkan apersepsi, penyampaian topik yang diajarkan, respon terhadap pertanyaan peserta didik, evaluasi pada tugas matematika, dan kesetimbangan antara tujuan dan evaluasi yang diberikan. Dari kedua sudut pandang tersebut, karakteristik pembelajaran matematika perlu dilihat sebagai suatu pembelajaran yang memerlukan perhatian khusus terhadap topik yang diajarkan serta secara khusus perlu diajarkan dengan memperhatikan karakteristik peserta didik dan ligkungan belajar.

Pembelajaran matematika juga mengambil peran penting dalam melaksanakan pendidikan karakter. Pada jenjang sekolah dasar pembelajaran tematik memudahkan guru mengaplikasikan nilai-nilai pendidikan karakter dalam pembelajaran matematika, dengan metode dan model pembelajaran yang sesuai dengan tematik serta dukungan media dan alat peraga lebih mengaktifkan siswa dalam belajar dan menyerap ilmu secara kontekstual.

Tema-tema pada sekolah dasar berkaitan erat dengan kehidupan sehari-hari siswa, demikian pula pembelajaran matematika sesuatu yang siswa alami dan pengalaman dalam sehari bermatematika. Dengan demikian, penyerapan dan penjelasan terkait matematka mudah dan siswa merasa senang dengan pelajaran matematika, tidak sebaliknya mengganggap matematika sulit. Dengan tematik siswa mengatahui lebih dulu tujuan belajar melalui pengalaman-pengalaman yang mereka alami dan berkaitan dengaan pembelajaran matematika.

\section{METODE}

Penelitian ini bertujuan untuk menggambarkan secara sistematik dan akurat fakta dan karakteristik mengenai populasi atau mengenai bidang tertentu. Pada penelitian ini berusaha untuk menggambarkan situasi dari data yang dikumpulkan yang semata-mata bersifat deskriptif sehingga tidak bermaksud mencari penjelasan, menguji hipotesis, membuat prediksi ataupun mempelajari implikasi (Saifudin Azwar, 2004).

Populasi penelitian ini seluruh guru kelas sekolah dasar (SD) di Kota Langsa yang tersebar pada 15 SD Sekota Langsa. Teknik pengambilan sampel menggunakan systematic random sampling. Sampel penelitian ini adalah guru kelas pada sekolah dasar yang berjumlah 212 orang terdiri dari 15 orang guru laki-laki dan 197 orang guru perempuan. Jumlah sampel yang terambil secara sistematis adalah 43 orang.

Alat pengumpul data penelitian yang digunakan adalah berbentuk angket, observasi, dan wawancara. Dalam penelitian ini analisis kuantitatif digunakan untuk memasukkan data ke dalam rumus statistik, sedangkan analisis kualitatif digunakan untuk menjelaskan data yang tidak bisa diangkakan. Sehingga dalam penelitian ini tidak memerlukan hipotesis, tetapi menggambarkan apa 
adanya tentang kemampuan pedagogi guru kelas di sekolah dasar Se-Kota Langsa dalam menerapkan pembelajaran tematik dengan mengimplementasikan nilai-nilai pendidikan karakter dalam sub tema matematik.

\section{HASIL PENELITIAN DAN PEMBAHASAN}

\section{Kompetensi Pedagogik Guru Kelas Pada Pembelajaran Matematika}

Penilaian terhadap kompetensi pedagogik guru SD Se-Kota Langsa dilakukan dengan memperhatikan delapan (8) aspek, yaitu: (a) Pemahaman wawasan atau landasan kependidikan; (b) Pemahaman terhadap anak didik; (c) Pengembangan kurikulum dan silabus; (d) Perancangan pembelajaran, (e) Pelaksanaan pembelajaran; (f) Evaluasi hasil belajar; (g) Pemanfaatan teknologi pembelajaran; dan (h) Pengembangan potensi anak didik. Penilaian pada komponen ini dapat dilihat pada Tabel 1.

Tabel 1 Penilaian Terhadap Kompetensi Pedagogik Guru Kelas

\begin{tabular}{|c|c|c|c|c|c|c|}
\hline \multirow[t]{2}{*}{ No } & \multirow{2}{*}{$\begin{array}{c}\text { Aspek } \\
\text { Pengamatan }\end{array}$} & \multicolumn{4}{|c|}{ Keterlaksanaan } & \multirow[t]{2}{*}{ Catatan Pengamatan } \\
\hline & & Ya & $\%$ & Tdk & $\%$ & \\
\hline \multicolumn{7}{|c|}{ Pemahaman wawasan atau landasan kependidikan } \\
\hline 1 & Penguasaan bahan ajar & 41 & 95 & 2 & 5 & \\
\hline 2 & $\begin{array}{l}\text { Hubungan yang baik antara } \\
\text { guru dan anak didik }\end{array}$ & 40 & 93 & 3 & 7 & \\
\hline 3 & $\begin{array}{l}\text { Kesesuaian strategi mengajar } \\
\text { dengan kondisi anak didik dan } \\
\text { mata pelajaran }\end{array}$ & 32 & 74 & 11 & 26 & \\
\hline \multicolumn{7}{|c|}{ Pemahaman terhadap anak didik } \\
\hline 4 & $\begin{array}{l}\text { Stimulasi anak didik untuk } \\
\text { bertanya dan menjawab }\end{array}$ & 8 & 19 & 35 & 81 & \\
\hline 5 & $\begin{array}{l}\text { Mendengar dengan baik } \\
\text { pertanyaan \& jawaban murid }\end{array}$ & 41 & 98 & 2 & 2 & \\
\hline 6 & $\begin{array}{l}\text { Menghargai murid aktif dan } \\
\text { pencapaian baik }\end{array}$ & 33 & 77 & 10 & 23 & 9 \\
\hline \multicolumn{7}{|c|}{ Pengembangan kurikulum dan silabus } \\
\hline 7 & $\begin{array}{l}\text { Pembelajaran sesuai dengan } \\
\text { RKH }\end{array}$ & 4 & 9 & 37 & 91 & $\begin{array}{l}2 \text { orang guru tidak } \\
\text { menunjukkan RPP }\end{array}$ \\
\hline 8 & Pengelolaan kelas & 41 & 98 & 2 & 2 & \\
\hline \multicolumn{7}{|c|}{ Perancangan dan pelaksanaan pembelajaran } \\
\hline 9 & Membentuk kelompok belajar & 15 & 35 & 28 & 65 & \\
\hline 10 & $\begin{array}{l}\text { Memacu keterlibatan anak } \\
\text { didik dalam pembelajaran }\end{array}$ & 39 & 90 & 4 & 10 & \\
\hline 11 & $\begin{array}{l}\text { Mengaitkan pelajaran dengan } \\
\text { dunia nyata }\end{array}$ & 16 & 37 & 27 & 63 & \\
\hline \multicolumn{7}{|c|}{ Evaluasi pembelajaran } \\
\hline 12 & $\begin{array}{l}\text { Melibatkan anak didik agar } \\
\text { aktif dalam belajar }\end{array}$ & 43 & 100 & 0 & 0 & \\
\hline 13 & $\begin{array}{l}\text { Membimbing anak didik dalam } \\
\text { penyelesaian soal }\end{array}$ & 32 & 74 & 11 & 26 & \\
\hline \multicolumn{7}{|c|}{ Pemanfaatan teknologi pembelajaran } \\
\hline 14 & $\begin{array}{l}\text { Memanfaatkan alat bantu } \\
\text { mengajar }\end{array}$ & 24 & 56 & 19 & 44 & \\
\hline 15 & $\begin{array}{l}\text { Memanfaatkan teknologi } \\
\text { sebagai sumber belajar }\end{array}$ & 3 & 7 & 40 & 93 & \\
\hline \multicolumn{7}{|c|}{ Pengembangan potensi anak didik } \\
\hline 16 & Relevansi matemari & 10 & 23 & 33 & 77 & \\
\hline & dengan nilai & & & & & \\
\hline
\end{tabular}




\begin{tabular}{llllll}
\hline & karakter & & & \\
17 & Pembelajaran asertif & 32 & 74 & 11 & 26 \\
18 & $\begin{array}{l}\text { Mengaitkan matematika } \\
\text { dengan sikap anak didik }\end{array}$ & 14 & 33 & 29 & 67 \\
19 & $\begin{array}{l}\text { Berbicara dengan jelas dan } \\
\text { santun }\end{array}$ & 100 & 0 & 0 \\
\hline
\end{tabular}

Berdasarkan Tabel 1. di atas dapat dijelaskan beberapa hal terkait dengan penilaian terhadap aspek kompetensi pedagogik guru:

a) Aspek pemahaman wawasan atau landasan kependidikan; dari analisis rata-rata indikator diperoleh $87,33 \%$ guru kelas matematika telah memahami aspek ini dengan baik, dan masih ada 12,67\% guru kelas tidak memahami aspke landasan kependidikan.

b) Aspek pemahaman terhadap anak didik; 64,66\% guru kelas telah memahami anak didik dengan baik sementara 35,34\% guru kelas belum memahami anak didik dengan baik.

c) Pengembangan kurikulum dan silabus; 58\% guru kelas sudah mampu mengembangkan kurikulum dan silabus matematika dengan baik, namun masih ada $42 \%$ guru kelas yang tidak mengembangkan kurikulum dan silabus pembelajaran matematika.

d) Perancangan dan pelaksanaan pembelajaran; hasil analisis observasi ditemukan 54\% guru kelas mampu mendesain dan melaksanakan pembelajaran matematika dengan menerapkan nilai karakter, selebihnya masih ada 46\% guru kelas yang tidak mampu mengimplementasikan aspek ini dengan baik.

e) Evaluasi pembelajaran; $87 \%$ guru kelas telah melakukan evaluasi pembelajaran matematika dengan baik, dan 13\% guru kelas masih tidak sistematis dalam melakukan evaluasi pembelajaran.

f) Pemanfaatan teknologi; hanya 31,5\% guru kelas yang sudah menggunakan teknologi dalam pembelajaran matematika, sementara $68,5 \%$ guru kelas masih mengandalkan pembelajaran secara konvensional.

g) Pengembangan potensi anak didik; 60\% guru kelas telah mampu mengembangkan semua aspek dari anak didik dalam pembelajaran matematika, dan $40 \%$ masih belum maksimal dalam mengembangkan aspek ini.

Sehingga dari hasil tersebut, diketahui bahwa rata-rata guru kelas SD Sekota Langsa masih perlu meningkatkan kompetensi pedagogiknya terutama dalam menanamkan nilai-nilai karakter pada pembelajaran matematika. Hal ini sangat penting untuk dilakukan karena kompetensi pedagogik ini merupakan salah satu kompetensi yang penting dikuasai oleh guru kelas.

\section{Penerapan Pendidikan Karakter Pada Pembelajaran Matematika}

Penilaian terhadap komponen proses pembelajaran merupakan kegiatan penilaian yang ditujukkan pada aspek pelaksanaan program pendidikan karakter dalam pembelajaran matematika.

a) Perencanaan Pembelajaran.

Berdasarkan hasil penilaian terhadap dokumen RKH guru yang mengajar matematika pada kelas 4 dan kelas 5 diperoleh sebanyak 42 orang guru $(89 \%)$ sudah mencantumkan identitas pelajaran dengan baik, 5 orang guru (11\%) saja yang kurang lengkap seperti ada RKH yang tidak menuliskan alokasi waktu dan ada pula yang tidak menuliskan materi ajar atau topik pelajaran yang dimaksud. Semua rancangan pembelajaran guru dinilai sudah baik dari segi penyusunan skenario pembelajaran, hanya 17 orang guru $(36 \%)$ saja yang kurang baik dalam menyusun RKH ditinjau dari segi penyesuaian nilai karakter dalam pembelajaran, mulai dari menyiapkan anak didik dan memotivasi mereka, menanamkan nilai karakter anak 
didik, metode dan media pembelajaran yang digunakan juga tidak terkait dengan nilai karakter yang akan dicapai.

b) Pelaksanaan dan Penilaian Pembelajaran Di Kelas.

Kegiatan pembelajaran yang direncanakan lebih menekankan pada aspek kognitif saja, bahkan penilaian proses dan penilaian hasil belajar juga tidak mengikutkan aspek karakter yang akan dicapai. Ditemukan 30 orang guru (64\%) sudah baik dalam melaksanakan pembelajaran, secara sengaja sudah mengaitkan pembelajaran dengan nilai karakter secara terancang mulai dari menyiapkan anak didik, memotivasi sampai kepada menilai proses dan hasil belajar sudah mengikutkan aspek nilai-nilai karakter yang sesuai dengan tema pelajaran matematika yang diajarkan dalam kelas. Pada langkah-langkah pembelajaran, guru harus mengaitkan antara alat ajar matematika dengan nilai pendidikan karakter, sehingga mudah untuk diterapkan dalam kelas. Penilaian proses dan penilaian hasil belajar dinilai sudah baik, semua guru mencantumkan penilaian dalam rancangan pembelajaran.

Namun demikian, didapati sebanyak 20 orang guru (43\%) mencantumkan penilaian kurang sesuai dengan indikator pembelajaran, penilaian pun tidak menyertakan aspek karakter dalam pembelajaran matematika. Sedangakan sebanyak 47 orang guru (57\%) sudah mencantumkan penilaian dengan baik dalam rancangan pembelajaran, penilaian juga menilai kepada aspek karakter dan keterampilan murid.

\section{Kendala Guru Dalam Penerapan Pendidikan Karakter}

Ada beberapa kendala yang dihadapi guru sekolah dasar dalam penerapan nilai karakter pada pembelajaran matematika. Dari hasil wawancara sebelum pengajaran dan peneliti mendapati:

1. Penyusunan RKH masih berdasarkan kurikulum KTSP, sebahagian guru belum menerapkan kurikulum 2013 dikarenakan secara teknis belum sepenuhnya dapat diimplementasikan di sekolah, buku untuk guru dan anak didik belum tersedia, pedoman kurikulum juga belum lengkap, terjadinya perubahan-perubahan yang menyulitkan guru dalam menerapkan nilai karakter di sekolah.

2. Sebahagian guru belum mendapatkan pelatihan berkaitan dengan pelaksanaan kurikulum 2013 terutama untuk menyusun RKH dan perangkat pembelajaran lainnya. Sehingga guru belum memiliki pengetahuan yang memadai berkaitan dengan kurikulum 2013, Guru beranggapan bahwa menyusun RPP matematika berbasis Kurikulum 2013 itu sulit.

3. Ditemukan kesamaan RKH guru dari sekolah yang bersamaan, dari pengakuan beberapa orang guru, mereka membuat RKH mengikut kepada RKH yang sudah disusun oleh teman sejawatnya, ada juga sebahagian guru yang meniru dari internet kemudian memodifikasi sesuai dengan keperluan mereka. Guru-guru mengakui bahwa menyusun RPP berdasarkan kurikulum 2013 tidak mudah, guru harus menyiapkan alat ajar, kaidah pembelajaran serta alat bantu mengajar yang tepat.

4. Distribusi buku pegangan anak diri sering terlambat sehingga menghambat pelaksanaan pembelajaran dan menghambat guru dalam menyusun RKH. Pihak sekolah hanya memberikan silabus, dan tidak memberikan format RKH Kurikulum 2013 yang baku atau sesuai pedoman implementasi Kurikulum 2013 (Permendikbud No. 81 A Tahun 2013). Memiliki alasan pribadi seperti kehamilan dan ketiadaan waktu untuk menyusun RKH, sibuk mengajar dengan jumlah jam mengajar yang padat, banyak menghabiskan waktu membuat alat bantu mengajar serta tidak memiliki dan tidak dapat menggunakan komputer juga menjadi alasan guru dalam menyusun RKH.

5. Permasalahan lainnya adalah bagi Sekolah Dasar yang di bawah pembinaan pemerintah daerah, implementasi kurikulum 2013 sempat terhenti dikarenakan tidak siap untuk 
menjalankannya. Setiap daerah memilik perbedaan kebijakan dan kesanggupan dalam pembiayaan pendidikan.

\section{KESIMPULAN}

Hasil penelitian menunjukkan bahwa 1) Guru telah menggunakan model, metode dan media pembelajaran serta sumber belajar yang sesuai dengan karakteristik anak juga karakteristik mata pelajaran matematika. Pendekatan tematik yang menjadi ciri khas pada sekolah kelas rendah juga selaras dengan konsep pelajaran matematika; 2) 26 guru (60,5\%) dinilai sudah baik dalam menyusun RKH dan 17 orang guru (39,5\%) masih kurang baik, dan 3) beberapa kendala yang dirasakan sulit pada penerapan nilai-nilai karakter adalah: a) Penyusunan RKH belum menerapkan kurikulum 2013, b) sebagian guru belum mendapatkan pelatihan untuk menyusun RKH dan perangkat pembelajaran lainnya, c) adanya kesamaan RKH guru dengan teman sejawat dan memodifikasi dari internet, d) distribusi buku sering terlambat sehingga menghambat pelaksanaan pembelajaran, dan e) adanya penghentian sementara dalam implementasi kurikulum 2013 akibat kebijakan dan keterbatasan dana Pemerintah Daerah.

\section{DAFTAR PUSTAKA}

E. Mulyasa. (2011). Menjadi Guru Profesional. Bandung: Remaja Rosdakarya . (2017). Nilai-Nilai Pendidikan Karakter Dalam Rancangan Pembelajaran Harian Guru Matematik Sekolah Rendah Kota Langsa-Aceh. Persidangan Antarabangsa Pedagogi Islam Dalam Pendidikan 2017 (1st ICIPE2017). Fakulti Pembangunan Manusia, UPSI, Malaysia.

Howard R.W., Berkowitz. M.W., \& Schaeffer E.F. (2004). Politics of Character Education , Educational Policy, Vol. 18 No. 1, January and March 2004 188-215 DOI: $10.1177 / 0895904803260031$

Kristanto, Vigih Hery (2011), pendidikan karakter dalam pembelajaran matematika pembentuk generasi antikorupsi, Widya Warta No. 01 Tahun XXXV / Januari 2011 ISSN 0854-1981

Sabaruddin \& Rosnidar. M (2016). Membangun "Performance Character \& Math Positivity" Dalam Pengajaran Dan Pembelajaran Matematik Sekolah Rendah. The 2016'S Tough Generation for a Better World International Conference, FKIP UNSYIAH, Banda Aceh.

Sabaruddin \& Rosnidar. M (2017). Nilai-Nilai Pendidikan Karakter Dalam Rancangan Pembelajaran Harian Guru Matematik Sekolah Rendah Kota Langsa-Aceh. Persidangan Antarabangsa Pedagogi Islam Dalam Pendidikan 2017 (1st ICIPE2017). Fakulti Pembangunan Manusia, UPSI, Malaysia.

Sabaruddin \& Rosnidar. M (2018). Parents Involvement in Improving Character of Children Through Mathematics Learning. Jurnal Ilmiah Peuradeun, 6(1), 41-50. doi:10.26811/peuradeun.v6i1.178

Shulman, L. S. (1986). Knowledge growth in teaching. Educational Researcher.15, 4-21.

Sumarmo, U. (2011). Pembelajaran Matematika Berbasis Pendidikan Karakter. In Prosiding Seminar Nasional Pendidikan Matematika STKIP Siliwangi Bandung (Vol. 1, pp. 22-33).

Sumarmo, U. (2011). Pembelajaran Matematika Berbasis Pendidikan Karakter. In Prosiding Seminar Nasional Pendidikan Matematika STKIP Siliwangi Bandung (Vol. 1, pp. 22-33).

Shulman, L. S. (1986). Knowledge growth in teaching. Educational Researcher.15, 4-21.

Undang-Undang Nomor 14 Tahun 2005 Tentang Guru dan Dosen. http://peraturan.go.id/uu/nomor-14-tahun-2005.html. 
Undang-Undang Nomor 16 Tahun 2007 Tentang Standar Kompetensi Guru. http://peraturan.go.id/pp/nomor-16-tahun-2007-

11e44c4ea6e1ddd08e1c313231353431.html.

Yuyus Kardiman. (2013). Karakter Adalah Akar Masalah Bangsa Kita, Media Komunikasi FIS Vol 12, No 2 Agustus 2013 